\title{
Seasonal Changes in the Phosphate Content of Sea Water in relation to the Growth of the Algal Plankton during 1923 and 1924.
}

\author{
By
}

W. R. G. Atkins, Sc.D.,

Head of the Department of General Physiology at the Plymouth Laboratory.

With Figures 1-8 in the Text.

CONTENTS.

Seasonal changes in the phosphate content at the L stations, from Plymouth Sound to E1

Seasonal changes in the phosphate content at Station El $\quad$. $\quad . \quad$. $\quad . \quad$. 702

Seasonal changes in the phosphate content of the water of the English Channel at the $\mathrm{E}$ and $\mathrm{N}$ stations. $. \quad . \quad . \quad . \quad . \quad . \quad .709$

Seasonal changes in the phosphate content of the water of the North Sea $\quad . \quad$. 714

Phosphate content of the Atlantic Ocean and other waters . . . . . . 716

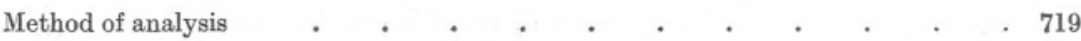

Summary . . . . . . . . . . . . . . . . . 720

\section{Seasonal Changes in the Phosphate Content at L Stations,} $1923-24$.

In Part I,* Table 5, are recorded the amounts of phosphate found at the L Stations up to August, 1923. These have been continued up to December, 1924, in the present paper, Table 1. It will be noted that high values are recorded for December, January, and February, that there is a marked fall in spring, so that during June, July, and, at some stations, August, the surface water is altogether or almost devoid of phosphate. Towards winter the values again rise. These results, therefore, confirm those of Part I and the values obtained by Matthews using the method of Pouget and Chouchak. In this and the following tables occasional high values are encountered, as in Part I. It is to be supposed that they are due to the enrichment of the locality sampled by the larger

* Vol. XIII, No. 1, of this Journal. 
members of the fauna or by passing vessels. Several records are given for September, including duplicate analyses performed after the water had been stored for ten days or a fortnight. These stored samples here show marked increases, due doubtless to decomposition. For this reason it is imperative that the water should be analysed for phosphate as soon as possible after it has been withdrawn from the sea. In other cases,

\section{TABLE I.}

Surface Values for Phosphate as $\mathrm{P}_{2} \mathrm{O}_{5}$ in $\mathrm{mg}$. per $\mathrm{m}^{3}$ from L1 to E1, 1923-24.

Station Sept. Oct. Nov. Dec. Jan. Jan. Feb. Mar. Apl. May June 13th 15th 8th 10th 2nd 14th 15th 10th 8th 20th 17th

$\begin{array}{lrrrrrrrrrrr}\text { L1 } & 23 & 12 & 36 & 40 & 23 & - & 35 & 8 \cdot 5 & 15 & - & 3 \\ \text { L2 } & 19 & 12 & 32 & 41 & 25 & - & 52 & 9 & - & - & 2 \\ \text { L3 } & 18 & 17 & 32 & 37 & 32 & 39 & 30 & 17 & 17 & - & 2 \\ \text { L4 } & 23 & 15 & 21 & -- & 31 & 39 & 35 & 15 \cdot 5 & - & - & - \\ \text { L5 } & 9 & 15 & 24 & 44 & 36 & 44 & 35 & 22 \cdot 5 & 16 & - & 3 \\ \text { L6 } & 7 & 21 & 23 & 40 & 68 & 37 & 36 & 10^{*} & - & - & - \\ \text { E1 } & 0 & 22 & 20 & 34 & 38 & - & 32 & - & \mathbf{1 4} \cdot 5 & \mathbf{5} & 2 \cdot 5\end{array}$

Analysed Sept. Oct. Nov. Dec. Jan. Jan. Feb. Mar. May June June 24th 16th 9th 11th 3rd 15th 18th 18th 2nd 20th 18th

Station July Aug. Sept. Sept. Sept. Sept. Sept. Oct. Nov. Dec. 9th 7th 3rd 18th 18th 22nd 22nd 1st 12th 9th

$\begin{array}{lllllllllll}\text { L1 } & 3 & 13 \cdot 5 & 28 & 14 & 19 & 8 & 17 \cdot 5 & - & 19 & 35 \\ \text { L2 } & 2 & 13.5 & 41 & 15 & - & 6 \cdot 5 & 36 \cdot 5 & 15 \cdot 5 & 19 & 35 \\ \text { L3 } & 2 & 8 & 28 & 9 \cdot 5 & 112 & 5 \cdot 5 & 12 & 11 & 21 & 35 \\ \text { L4 } & 0 & 2 & 32 & 7 \cdot 5 & 16 & 6 & 8.5 & 12 & 15 & 36 \ddagger \\ \text { L5 } & 0 & 1.5 & 15 & - & - & - & - & 12 & 33 & 33 \\ \text { L6 } & 1 & 9 \dagger & 23.5 & - & - & - & - & 12 & 22 & 31 \\ \text { E1 } & 2.5 & 1.5 & 12 & - & - & - & - & 6 & 14 & 32\end{array}$

Analysed July Aug. Sept. Sept. Oct. Sept. Oct. Oct. Nov. Dec. 17th 9th 17th 19th 2nd 23rd 2nd 2nd 14th 10th

however, storage is accompanied by a decrease in phosphate; examples of this are given later.

In Table 2 are shown the values obtained at $\mathrm{E} 1$ and $\mathrm{L}$ series at various depths during summer and autumn. It may be seen that as the coast is approached the water undergoes a greater degree of vertical mixing and the thickness of the warm layer devoid of phosphate, the epithalassa, becomes reduced.

* But 24 at $25 \mathrm{~m}$. $\quad$ But 2 at $10 \mathrm{~m}$. $\quad$ Same near bottom, $40 \mathrm{~m}$. 


\section{TABLE II.}

Variation of phosphate with depth as coast is approached on Aug. 7th, Sept. 3rd, Oct. 1st and Nov. 12th. Analysed Aug. 9th, Sept. 17th, Oct. 2nd and Nov. 14th, 1924, respectively.

\begin{tabular}{|c|c|c|c|c|c|c|c|c|c|c|c|c|c|c|c|c|}
\hline Depth & E1 & L6 & L5 & L4 & L3 & El & L6 & L5 & L4 & L3 & El & L6 & $\mathrm{L} 4$ & L3 & E1 & L4 \\
\hline 0 & $1 \cdot 5$ & 9 & 1.5 & 2 & 8 & 12 & $23 \cdot 5$ & 15 & 32 & 28 & 6 & 12 & 12 & 11 & 14 & 15 \\
\hline 5 & 2 & - & 2 & 2 & 7 & 10 & - & - & - & - & - & - & - & - & 20 & - \\
\hline 10 & - & 2 & - & 3 & $6 \cdot 5$ & $19 \cdot 5$ & - & 16 & 11 & - & 14 & - & - & - & - & 26.5 \\
\hline 15 & 1 & $5 \cdot 5$ & 9 & 6 & $9 \cdot 5$ & 14 & - & - & - & - & - & - & - & - & - & - \\
\hline 20 & 13 & $5 \cdot 5$ & - & - & - & 19 & $\overline{0}$ & 35 & $\overline{01}$ & - & - & - & - & - & $\overline{0}$ & - \\
\hline 25 & 13 & $10 \cdot 5$ & 8 & $5 \cdot 5$ & - & 19 & $24 \cdot 5$ & - & 21 & - & - & - & - & - & 20 & - \\
\hline 30 & - & - & - & - & $\overline{0}$ & - & - & - & - & 16 & - & - & - & - & - & - \\
\hline 40 & - & - & $12 \cdot 5$ & - & 12 & - & - & - & - & - & - & $\overline{-}$ & - & - & - & 26 \\
\hline 50 & - & - & - & 12 & * & 19 & - & 19 & 21 & * & 16 & $15 \cdot 5$ & $15 \cdot 5$ & $*$ & - & - \\
\hline 60 & - & - & * & * & * & - & 24 & * & $*$ & * & - & - & $*$ & $*$ & - & * \\
\hline 70 & 13 & * & * & * & $*$ & 19 & * & * & $*$ & * & 16 & * & * & $*$ & 21 & * \\
\hline
\end{tabular}

Seasonal Changes in the Phosphate Content at Station E1, 1923-24.

In Table 3 the values given in Part I, Table 7, are continued, and the data for the two years are plotted in Figs. 1 and 2, for surface and bottom respectively. It may be noticed that while the two years show a general similarity, yet the decrease in phosphate became marked in 1924 at a

\section{TABLE III.}

Seasonal Changes at Station E1. The Figures denote Phosphate as $\mathrm{P}_{2} \mathrm{O}_{5}$ in mg. per $\mathrm{m}^{3}$, 1923-24.

Depth Sept. Oct. Nov. Dec. Jan. Feb. Mar. Apl. 13th 15th 7th 10th 2nd 15th 10th 8th

$\begin{array}{ccccccccc}0 & 0 & 22 & 20 & 34 & 38 & 32 & 12 & 14 \cdot 5 \\ 5 & 1 & 21 & - & - & - & 32 & - & - \\ 10 & 6 & 18 & - & - & - & - & - & - \\ 15 & - & - & - & 34 & - & - & - & - \\ 20 & 13 & 16 & - & - & - & - & - & - \\ 25 & - & 13 & - & - & - & - & 27 & 15 \\ 30 & - & 19 & - & - & - & - & - & - \\ 40 & 17 & 15 & - & - & - & - & - & - \\ 50 & - & 14 & 20 & - & 36 & - & - & - \\ 70 & 20 & 14 & 20 & 34 & - & 32 & 22 & 15 \\ \text { nalysed } & \text { Sept. } & \text { Oct. } & \text { Nov. } & \text { Dec. } & \text { Jan. } & \text { Feb. } & \text { Mar. } & \text { May } \\ & \text { 24th } & 16 \text { th } & 9 \text { th } & \text { 11th } & \text { 3rd } & \text { 18th } & \text { 18th } & \text { 2nd }\end{array}$


Seasonal Changes in the Phosphate Content of Sea Water at Station E1, Surface.

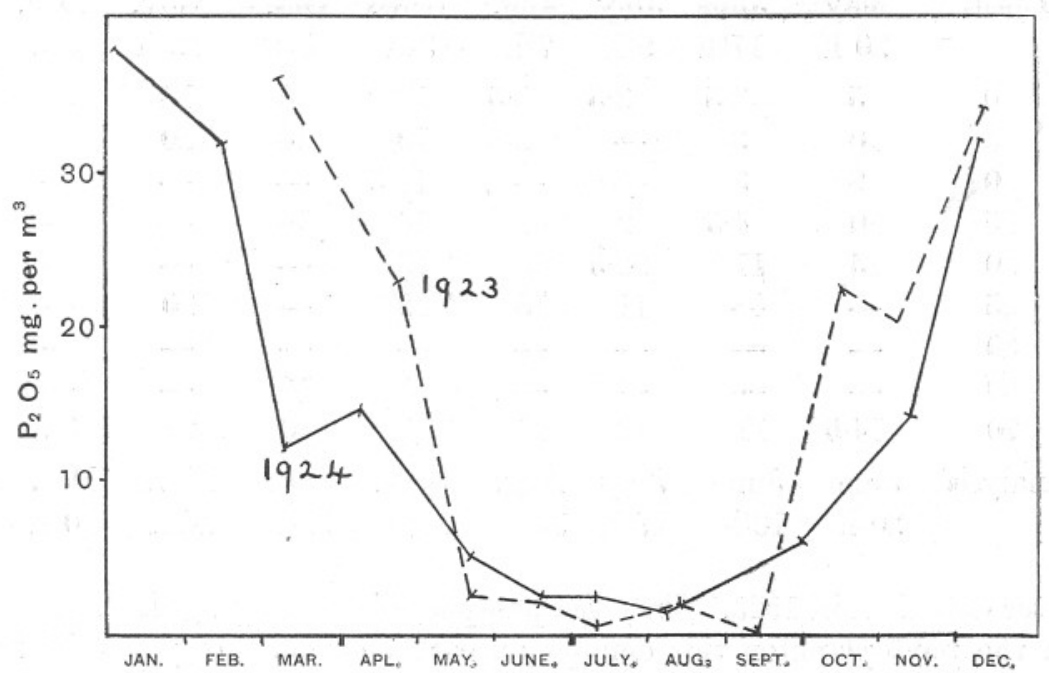

Frg. 1.-The ordinates denote phosphate, shown as milligrams of $\mathrm{P}_{2} \mathrm{O}_{5}$ per cubic metre of water. The abscissæ are months during 1923 and 1924.

Seasonal Changes in the Phosphate Content of Sea Water at Station E1, Bottom, 70 Metres.

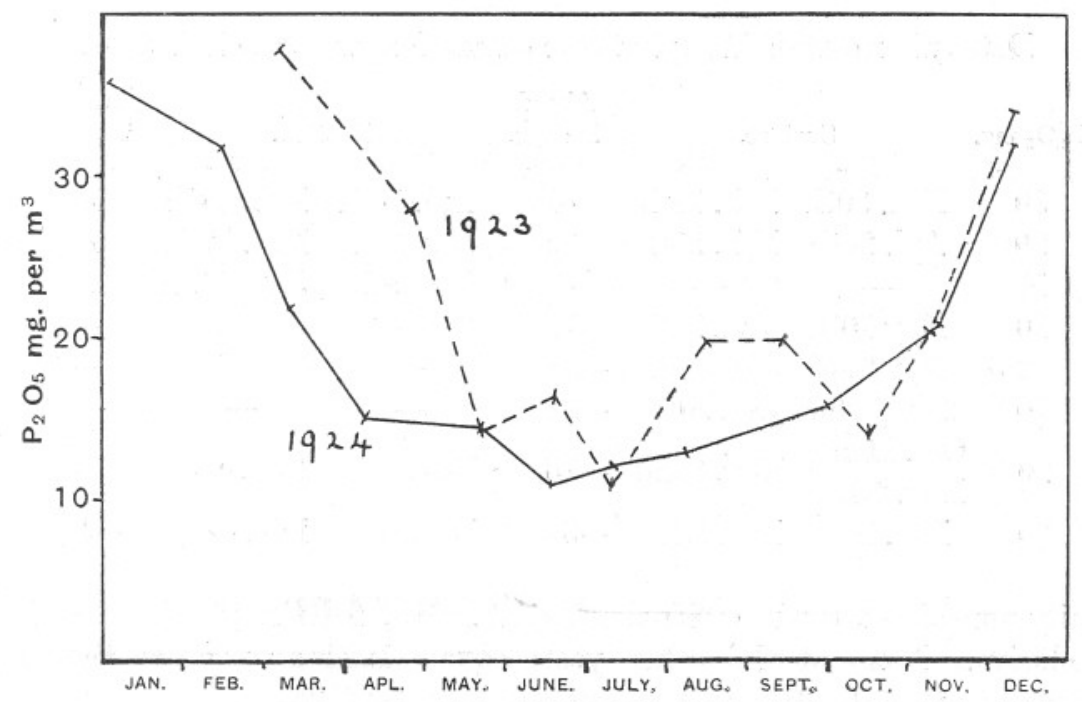

FIG. 2.-The ordinates denote phosphate, shown as milligrams of $\mathrm{P}_{2} \mathrm{O}_{5}$ per cubic metre of water. 
TABLE III-continued.

$\begin{array}{ccccccccc}\text { Depth } & \text { May } & \text { June } & \text { July } & \text { Aug. } & \text { Sept. } & \text { Oct. } & \text { Nov. } & \text { Dec. } \\ & 20 \text { th } & 17 \text { th } & 9 \text { th } & 7 \text { th } & \text { 3rd } & \text { 1st } & 12 \text { th } & 9 \text { th } \\ 0 & 5 & 2 \cdot 5 & 2 \cdot 5 & 1 \cdot 5 & 12 & 6 & 14 & 32 \\ 5 & 10 & 3 & - & 2 & 10 & 14 & 20 & - \\ 10 & 9 & 3 & - & - & 19 \cdot 5 & - & - & - \\ 15 & 10 & 4 \cdot 5 & 2 & 1 & 14 & 14 & - & - \\ 20 & 15 & 11 & 22 \cdot 5 & 13 & 19 & - & - & 32 \\ 25 & - & - & 11 & 13 & 19 & - & 20 & - \\ 30 & - & - & - & - & - & - & - & - \\ 50 & - & - & - & - & 19 & 16 & - & - \\ 70 & 14 \cdot 5 & 11 & 12 & 13 & 19 & 16 & 21 & 32 \\ \text { Analysed } & \text { June } & \text { June } & \text { July } & \text { Aug. } & \text { Sept. } & \text { Oct. } & \text { Nov. } & \text { Dec. } \\ & 20 \text { th } & 18 \text { th } & 17 \text { th } & 9 \text { th } & 17 \text { th } & 2 \text { nd } & 14 \text { th } & 10 \text { th }\end{array}$

later date than in 1923. Since the phosphate is used up by the increase in the phytoplankton this denotes an earlier outburst of plant life in 1924 than in 1923, which appears to be due to the high value for the mean daily sunshine during March, 1924, 5·3 hrs., as compared with $3.5 \mathrm{hrs}$. in 1923. Fig. 3 shows the values of the monthly means of the

\section{TABLE IV.}

Dates when certain Phosphate Concentrations were reached at E1.

\begin{tabular}{|c|c|c|c|c|c|c|}
\hline \multirow{2}{*}{$\begin{array}{l}\mathrm{P}_{2} \mathrm{O}_{5} \mathrm{mg} . \\
\text { per m. }\end{array}$} & \multicolumn{2}{|c|}{ Surface. } & \multirow{2}{*}{$\begin{array}{c}\text { Ahead } \\
\text { in days, } \\
1924 .\end{array}$} & \multicolumn{2}{|c|}{ Bottom. } & \multirow{2}{*}{$\begin{array}{l}\text { Ahear } \\
\text { in day } \\
1924 .\end{array}$} \\
\hline & 1923. & 1924 & & 1923. & 1924. & \\
\hline 30 & Mar. 30th & Feb. 18th & 41 & Apl. 14th & Feb. 20th & 54 \\
\hline 20 & Apl. 28th & Feb. 28th & 29 & May 9 th & Mar. 17th & 53 \\
\hline 11 & - & - & - & July 9 th & June 1 & 21 \\
\hline 10 & May 10th & Apl. 28th & 12 & - & - & - \\
\hline $2 \cdot 5$ & May 21st & June 18th & -28 & - & - & - \\
\hline 10 & Sept. 28th & Oct. 20 th & -22 & - & - & - \\
\hline 20 & $\begin{array}{l}\text { Oct. 11th } \\
\text { Nov. 7th }\end{array}$ & Nov. 22nd & -15 & 6 th & v. 4th & 2 \\
\hline 30 & Dec. 1st & Dec. 6th & -5 & Dec. 1st & Dec. 4 th & -3 \\
\hline
\end{tabular}

daily sunshine records of England, S.W. area, for the years 1921-24 inclusive. None of the other years equals 1924 as regards March sunshine, though 1921 stands out as an exceptional year in April, June, and July. 
The graphs in Figs. 1 and 2 give approximate information as to the periods of the year when the development of the phytoplankton was most rapid, and Table 4 constitutes a comparison of 1923 with 1924 obtained by reading off the dates at which certain concentrations were reached in the periods of consumption and of regeneration of phosphate. Thus in 1924 consumption was far ahead of 1923 in the spring and regeneration lagged somewhat at first, though eventually the two years

\section{Mean Monthly Values for Daily Sunshine in England, S.W. Area.}

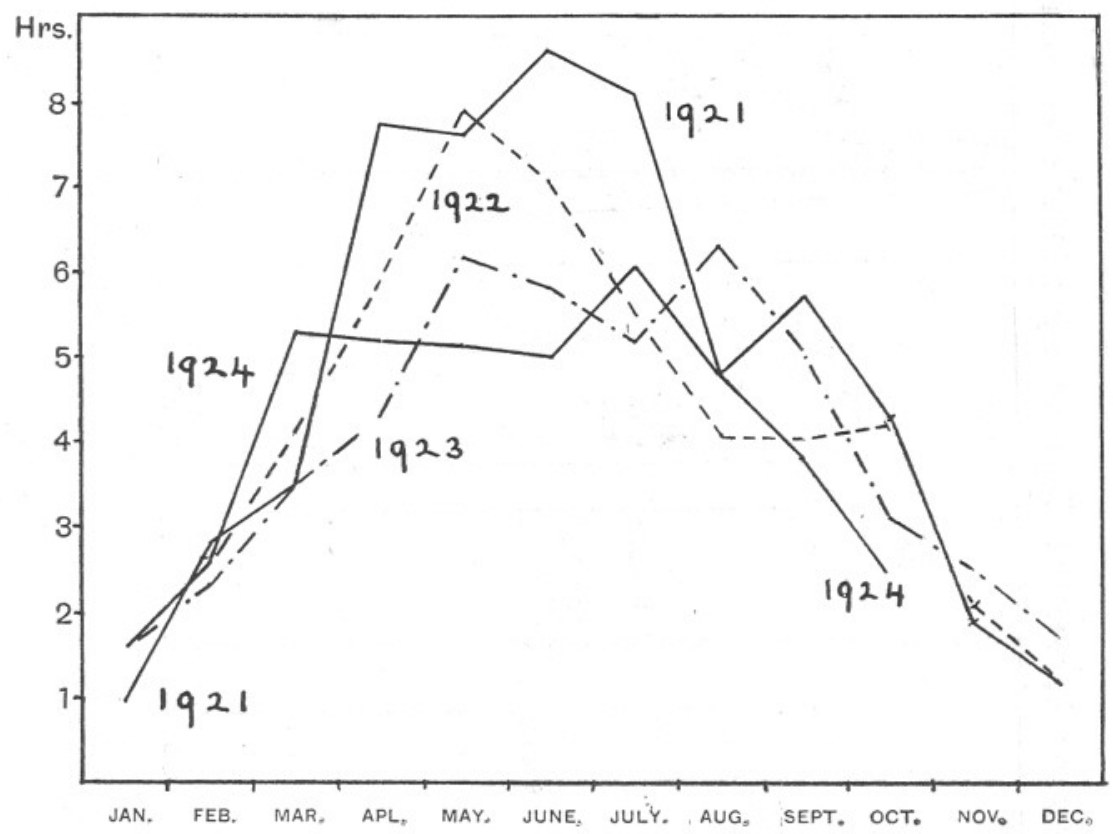

FIG. 3.-The ordinates denote the number of hours of sunshine daily for the month plotted for the 15th of each month.

ran out almost level. Furthermore, the two years were closely similar in the extent to which phosphate was removed from the water column in the open sea, as shown by the E1 results. The values given in Table 3 for the phosphate-depth series are shown in Fig. 4, which should be compared with Pt. I, Fig. 5, p. 131. The monthly graphs move towards the right, denoting increase in phosphate in the latter half of each year, and towards the left in the first half. Now from the area of the curve between the June 17th graph and the vertical axis it may be found that the water column contained $61.2 \mathrm{mg}$. phosphate, as $\mathrm{P}_{2} \mathrm{O}_{5}$, in $70 \mathrm{~m}^{3}$, 
down to the bottom, viz. 8.7 per $\mathrm{m}^{3}$. Similarly for July the amount was $61 \cdot 3 \mathrm{mg}$., or $8 \cdot 7$ per $\mathrm{m}^{3}$. During this period there was accordingly no.

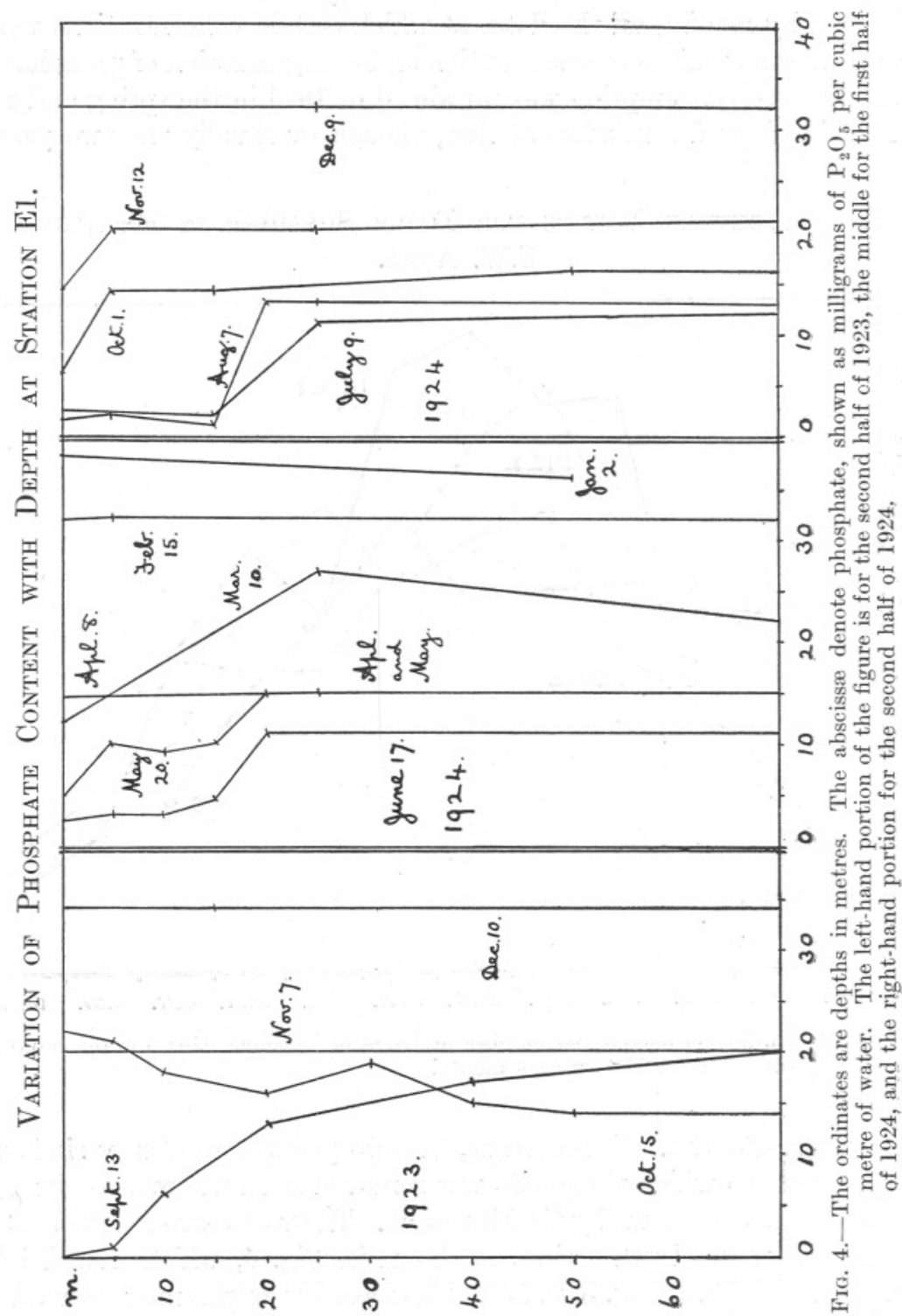

further growth, for the phosphate left over was far from the light. To. be accurate there was some growth, as the surface waters were more nearly being completely deprived of phosphate in July than in June, 
but this was counterbalanced by regeneration in the deeper water. Subtracting these amounts, viz. 8.7 per $\mathrm{m}^{3}$ from that present in January, $37 \mathrm{mg}$. per $\mathrm{m}^{3}$, it is seen that $28 \cdot 3 \mathrm{mg}$. per $\mathrm{m}^{3}$ was used up. For 1923 the corresponding figures were 37 and $7 \cdot 4$, giving a consumption of $29.6 \mathrm{mg}$. per $\mathrm{m}^{3}$. Accordingly, the 1923 estimate of $1.4 \mathrm{kgm}$. algalplankton, wet weight, per square metre of sea down to 70 metres holds quite approximately for 1924 also.

Seasonal Changes in the Temperature of the Water at Station E1, Surface.

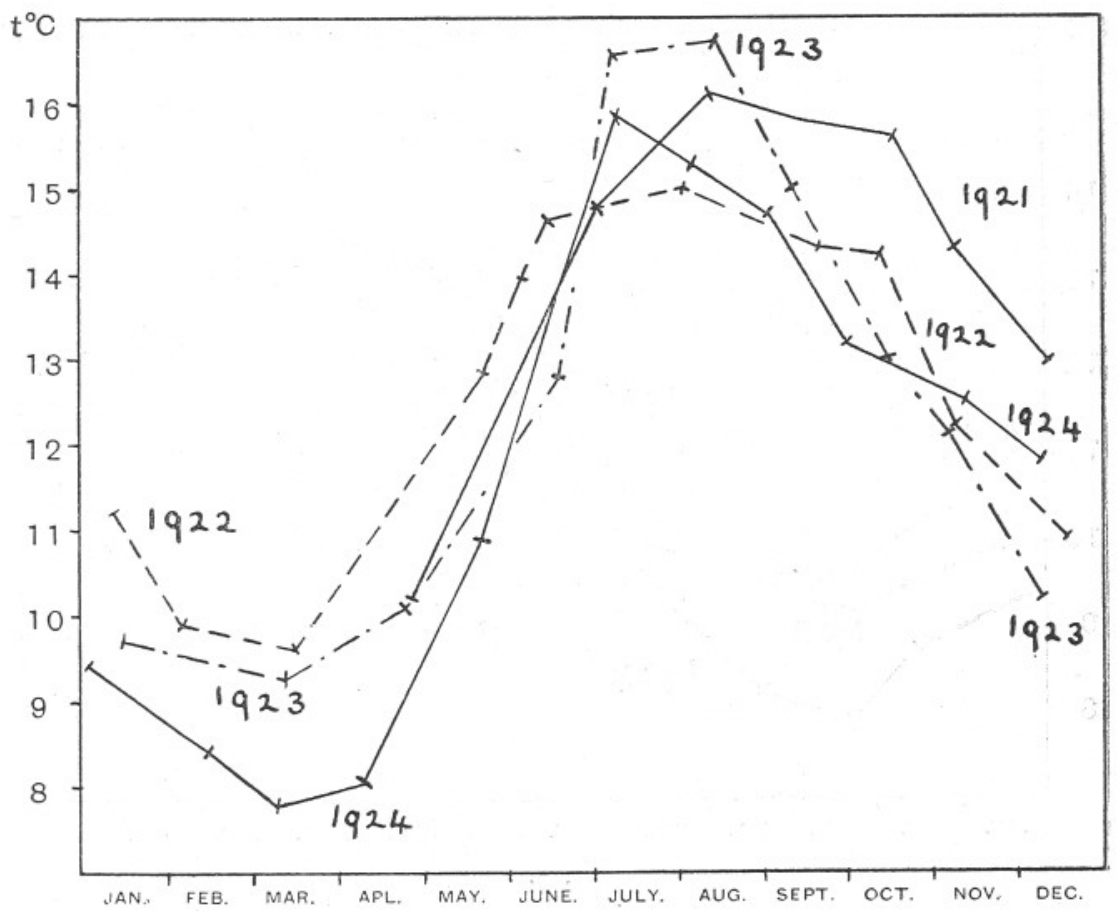

FIG. 5 .

Table 5 is similar in construction to Table 4, but shows temperatures instead of phosphate concentrations. It was drawn up by reading off from Figs. 5 and 6, which are plotted from the surface and bottom $(70 \mathrm{~m}$.) observations made at E1 from 1921-24 inclusive. In these it may be seen that 1924 was the coldest year in the spring, a condition which persisted till November at the bottom. Moreover, no two years were the same. In view of the very high temperature coefficient which living cells show as regards all their processes of metabolism, these differences 
must have a considerable importance in regulating their rates of growth and the onset of periods of reproduction.

Thus we are faced with the fact that in 1924 the water in spring was abnormally cold, and the attainment of given temperatures lagged over a month-two months at the bottom-behind 1923, yet owing to the greater amount of sunshine the phosphate consumption in 1924 was over a month ahead of 1923 . Therefore, it appears that in 1924 the rate of

Seasonal Changes in the Temperature of the Water at Station E1, Воттом.

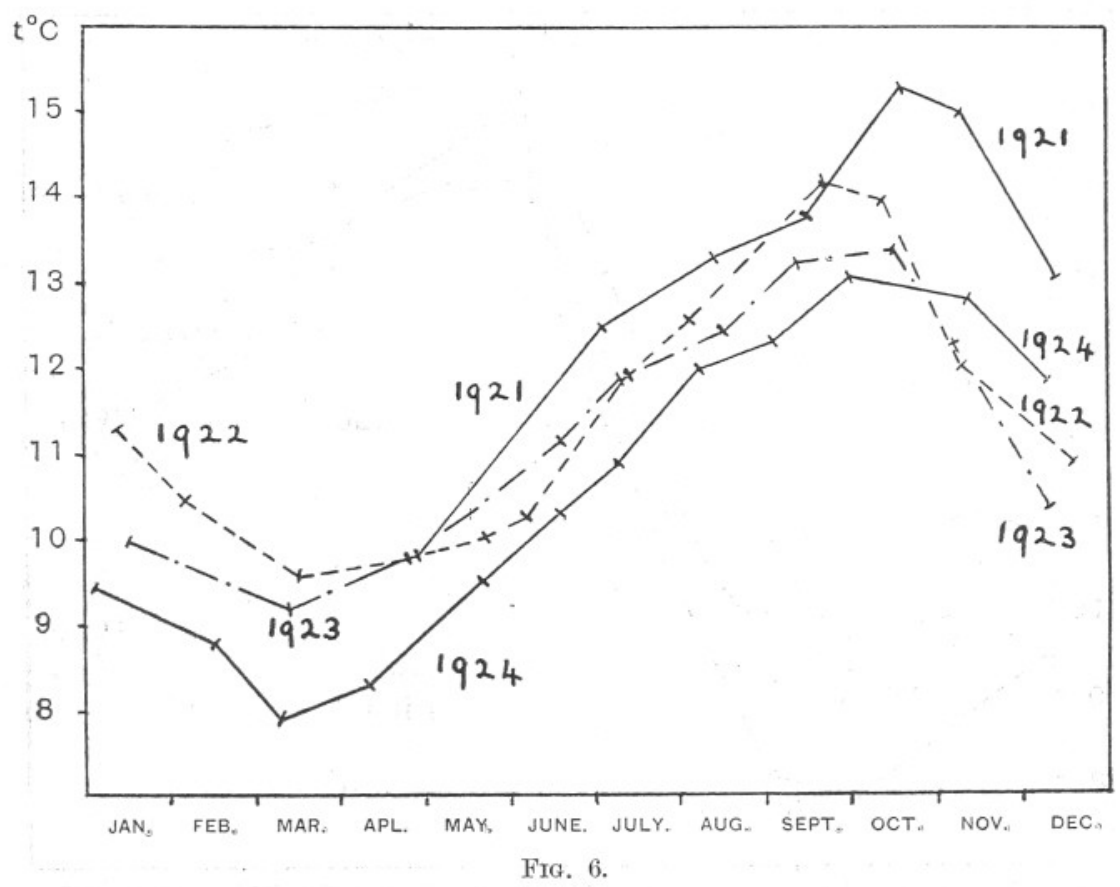

production of the phytoplankton was far ahead of that of the zooplankton as compared with 1923. It is possible that a difference of this kind may affect certain species of the latter advantageously, in that their food supply is abundant, or adversely if it so happens that the particular food organism required has appeared and disappeared again, as for example. Phæocystis is known to do.

Similar seasonal changes in the phosphate content of fresh-water ponds have been found by the author and Harris (1924); an abstract is published in this Journal. 


\section{TABLE V.}

Dates when Certain Temperatures were reached at E1.

\begin{tabular}{ccccccc} 
& \multicolumn{2}{c}{ Surface. } & Ahead & \multicolumn{2}{c}{ in days, } & \multicolumn{2}{c}{ Bottom. } & Ahead \\
in days, \\
t.
\end{tabular}

Seasonal Changes in the Phosphate Content of the Water of - the English Channel at the E and N Stations.

The positions of the stations are shown in the map given on p. 754, Vol. 12, No. 4, of this Journal; the E series form a line from Plymouth to Ushant and the $\mathrm{N}$ from Ushant to Cork, N2 being near the Bishop Light, S.E. of the Scillies. N3, however, is in the passage between the islands and Cornwall. The results from Nov., 1923-Nov., 1924, inclusive are shown in Tables 6, 7, 8, and 9, also in Figs. 7 and $8:$ these should be compared with Tables 8 and 9 and Figs. 6 and 7 in Part I, this Journal, p. 132, Vol. 13, No. 1. These stations illustrate the fact that the seasonal changes occur in very much the same manner at all the localities investigated, though the smaller number of observations renders the sequence less detailed. On comparing the two years it is seen that phosphate consumption had progressed slightly further by May, 1923, than by May, 1924, at E2 and E3, while at N1 and N2 the seasons were very much alike. In July, 1924, E2 was either behind 1923, or more probably in view of the high surface values rather ahead of it on the path towards regeneration of phosphate. At E3 the two years were very similar, as also at N2. At N1 the surface water was more completely denuded of phosphate in 1923, but the deeper water was the poorer in 1924, so that on the whole the two years were much alike. The November results all indicated that either owing to more rapid regeneration or to the influx of water richer in phosphate the water in 1924 was rather better supplied with phosphate than in 1923. These differences are, however, all of a minor kind; in general the seasonal changes were alike.

Tables 6-9 also record the temperature observations as well as the phosphate content. On comparing the two sets of figures it becomes 
apparent that the warm layer, the epithalassa, is also the region of low phosphate content. Thus in July, 1924, at El the epithalassa extends

Variation of Phosphate Content with Depth at. Stations

E2 AND E3.

Station E 2.

Station E 3.

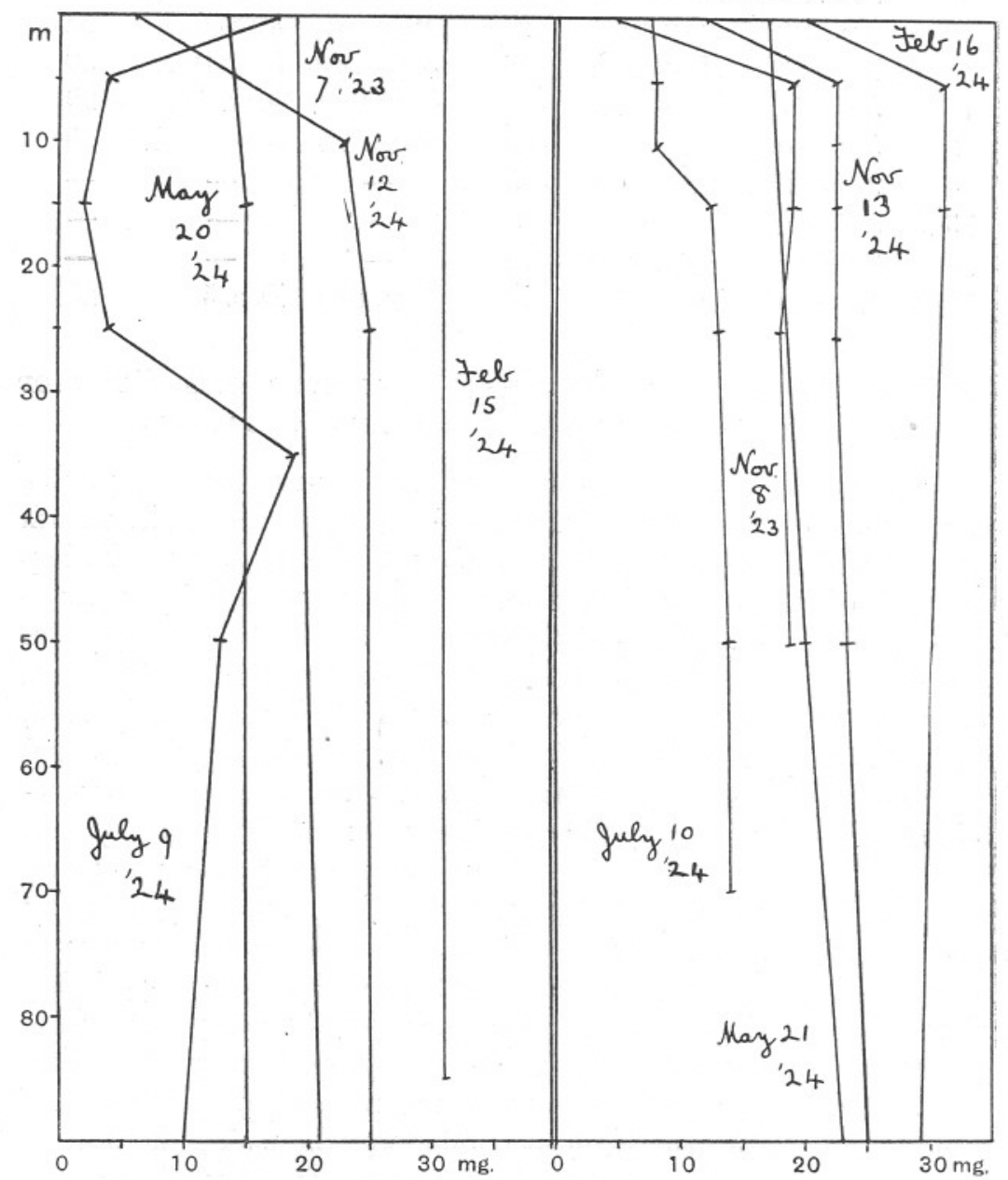

FIG. 7.-The ordinates are depths in metres. The abscissæ denote phosphate, shown as milligrams of $\mathrm{P}_{2} \mathrm{O}_{5}$ per cubic metre of water. The left-hand portion is for E2.

to 15 metres, with a $\mathrm{P}_{8} \mathrm{O}_{5}$ value of $2 \mathrm{mg}$., whereas at $\mathrm{E} 2$, where the epithalassa extends to $25 \mathrm{~m}$., the low value, $4 \mathrm{mg}$., is found at that depth. Other examples may be noted elsewhere in the tables. This is quite in keeping with the results afforded by hydrogen ion concentration measure- 
ments as recorded in the writer's previous papers in this Journal. It appears to be indicated also in Table 8 that the thermocline may be rather richer in phosphate than the hypothalassa, due probably to its

\section{Variation of Phosphate Content with Depth at Stations N1 AND N2.}

\section{Station $\mathrm{N} 1$.}

Station N 2.

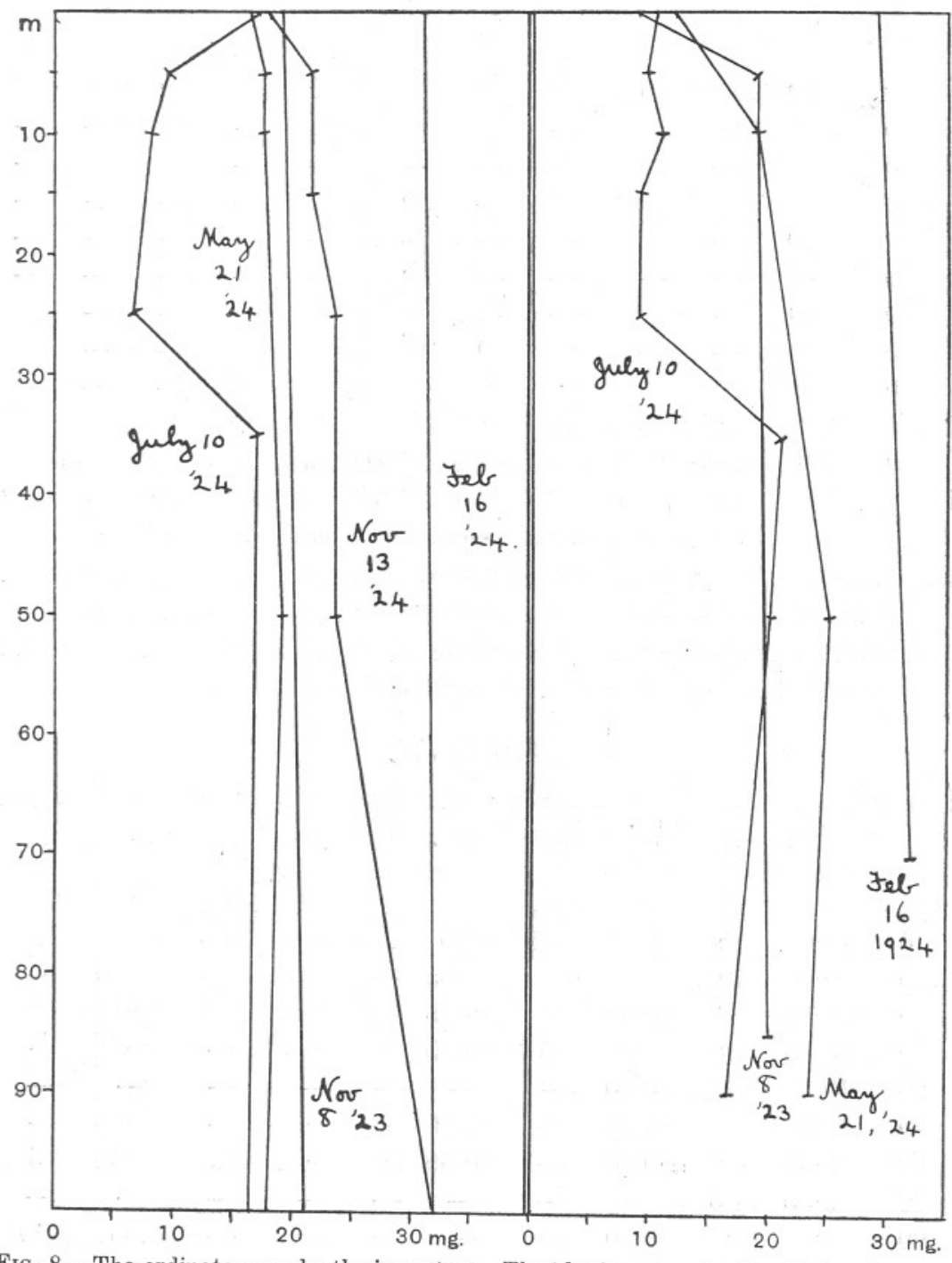

FIG. 8.-The ordinates are depths in metres. The abscissæ denote phosphate, shown as milligrams of $\mathrm{P}_{2} \mathrm{O}_{5}$ per cubic metre of water. The left-hand portion is for N1. 
being relatively rich in zooplankton, though it is quite possible that the high values found in a few cases may have been occasioned by fortuitous contamination of the water before it was drawn.

\section{TABLE VI.}

Phosphate as $\mathrm{P}_{2} \mathrm{O}_{5}$ in $\mathrm{mg}$. per $\mathrm{m}^{3}$ on cruises of Nov. 7th-8th, 1923, and Feb. 15th-16th, 1924, respectively. Surface and bottom temperatures are shown below. Analysed Nov. 9th and Feb. 18th respectively.

$$
\begin{array}{ccccccc|ccccc}
\text { Depth } & \text { E1 } & \text { E2 } & \text { E3 } & \text { N1 } & \text { N2 } & \text { N3 } & \text { E1 } & \text { E2 } & \text { E3 } & \text { N1 } & \text { Z } \\
0 & 20 & 19 & 5 & 19 & 9 & 7 & 32 & 31 & 20 & 31 & 29 \\
5 & - & - & 19 & - & 19 & 18 & 32 & - & 31 & - & - \\
15 & - & - & 19 & - & - & - & - & - & 31 & - & - \\
25 & - & - & 18 & - & - & 20 & - & - & - & - & - \\
50 & 20 & - & 19 & - & - & - & - & - & - & - & - \\
65 & - & - & - & - & - & 20 & - & - & - & - & - \\
70 & 20 & - & - & - & - & * & 32 & - & - & - & 32 \\
85 & * & - & - & - & 20 & * & * & 31 & - & - & * \\
95 & * & 21 & - & - & * & * & * & * & - & - & * \\
105 & * & * & - & 21 & * & * & * & * & 29 & 32 & * \\
0 & 12.15 & 12.3511 \cdot 15 & 11.6511 .6511 .55 & 8.45 & 9.45 & 9.55 & 9.55 & 8.8 \\
\text { Bottom } & 12.32 & 12.6311 .85 \dagger 11.7011 .70 & 11.72 & 8.76 & 9.63 & 10.03 & 9.85 & 9.00
\end{array}
$$

The stations form an open V with E3 at apex and E2 opposite N1. Station

$\mathrm{Z}$ was an extra observation point 20 miles S.W. of the Lizard, as weather did not permit of N2 being reached. Asterisks in a column signify that bottom would be penetrated at the depth.

\begin{tabular}{|c|c|c|c|c|c|c|c|c|c|c|}
\hline \multirow[b]{2}{*}{ Depth } & \multicolumn{2}{|c|}{ E1 } & \multicolumn{2}{|c|}{ E2 } & \multicolumn{2}{|c|}{ E3 } & \multicolumn{2}{|c|}{$\mathrm{Nl}$} & \multicolumn{2}{|c|}{ N2 } \\
\hline & $t^{\circ}$ & $\mathrm{P}_{2} \mathrm{O}_{5}$ & $t^{\circ}$ & $\mathrm{P}_{2} \mathrm{O}_{5}$ & $t^{\circ}$ & $\mathrm{P}_{2} \mathrm{O}_{5}$ & $t^{\circ}$ & $\mathrm{P}_{2} \mathrm{O}_{5}$ & $t^{\circ}$ & $\mathrm{P}_{2} \mathrm{O}_{5}$ \\
\hline 0 & $10 \cdot 9$ & 5 & $10 \cdot 8$ & $13 \cdot 5$ & 10.5 & 17 & $11 \cdot 4$ & $16 \cdot 5$ & $11 \cdot 7$ & 12 \\
\hline 5 & $10 \cdot 94$ & 10 & 10.56 & - & $10 \cdot 55$ & - & $11 \cdot 52$ & $17 \cdot 5$ & $11 \cdot 40$ & - \\
\hline 10 & $10 \cdot 84$ & 9 & $10 \cdot 56$ & - & 10.55 & - & $11 \cdot 51$ & $17 \cdot 5$ & $10 \cdot 74$ & 19 \\
\hline 15 & $10 \cdot 45$ & 10 & $10 \cdot 56$ & 15 & $10 \cdot 55$ & - & $10 \cdot 25$ & - & $9 \cdot 74$ & - \\
\hline 20 & $10 \cdot 32$ & 15 & $10 \cdot 30$ & - & - & - & - & - & - & - \\
\hline 25 & $9 \cdot 59$ & - & $10 \cdot 24$ & - & $10 \cdot 60$ & - & $9 \cdot 79$ & - & $9 \cdot 74$ & - \\
\hline 50 & $9 \cdot 57$ & - & $10 \cdot 20$ & - & 10.59 & 20 & $9 \cdot 79$ & 19 & $9 \cdot 54$ & 25 \\
\hline 70 & $9 \cdot 55$ & $14 \cdot 5$ & - & - & - & - & - & - & - & - \\
\hline 90 & * & * & $10 \cdot 20$ & 15 & - & - & - & - & $9 \cdot 51$ & $23 \cdot 5$ \\
\hline 100 & * & $*$ & * & $*$ & $10 \cdot 59$ & 23 & $9 \cdot 74$ & 18 & $*$ & 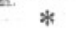 \\
\hline
\end{tabular}

\section{TABLE VII.}

Phosphate as $\mathrm{P}_{2} \mathrm{O}_{5}$ in mg. per $\mathrm{m}^{3}$ on cruise of May 20th-21st, 1924. Temperatures are also shown. Analysed June 20th. 


\section{TABLE VIII.}

Phosphate as $\mathrm{P}_{2} \mathrm{O}_{5}$ in mg. per $\mathrm{m}^{3}$ on cruise of July 9th-10th, 1924 .

Temperatures are also shown. Analysed July 17th.

\begin{tabular}{cccccccccccccc} 
& \multicolumn{4}{c}{$\mathrm{E} 1$} & \multicolumn{2}{c}{$\mathrm{E} 2$} & \multicolumn{2}{c}{$\mathrm{E} 3$} & \multicolumn{2}{c}{$\mathrm{N1}$} & \multicolumn{2}{c}{$\mathrm{N} 2$} & \multicolumn{2}{c}{$\mathrm{N} 3$} \\
Depth & $t^{\circ}$ & $\mathrm{P}_{2} \mathrm{O}_{5}$ & $\mathrm{t}^{\circ}$ & $\mathrm{P}_{2} \mathrm{O}_{5}$ & $\mathrm{t}^{\circ}$ & $\mathrm{P}_{2} \mathrm{O}_{5}$ & $t^{\circ}$ & $\mathrm{P}_{2} \mathrm{O}_{5}$ & $t^{\circ}$ & $\mathrm{P}_{2} \mathrm{O}_{5}$ & $t^{\circ}$ & $\mathrm{P}_{2} \mathrm{O}_{5}$ \\
0 & $15 \cdot 9$ & $2 \cdot 5$ & $15 \cdot 7$ & $17 \cdot 5$ & $15 \cdot 2$ & $7 \cdot 5$ & $15 \cdot 5$ & 17 & $15 \cdot 2$ & $10 \cdot 5$ & $15 \cdot 0$ & $11 \cdot 5$ \\
5 & $14 \cdot 38$ & - & $15 \cdot 53$ & 4 & $15 \cdot 23$ & 8 & $15 \cdot 43$ & $9 \cdot 5$ & $14 \cdot 81$ & $9 \cdot 5$ & $15 \cdot 19$ & 7 \\
10 & $14 \cdot 20$ & - & - & - & $14 \cdot 83$ & 8 & $15 \cdot 36$ & 8 & $13 \cdot 53$ & 11 & $14 \cdot 90$ & 6 \\
15 & $13 \cdot 45$ & 2 & $14 \cdot 43$ & 2 & $12 \cdot 69$ & $12 \cdot 5$ & $14 \cdot 66$ & - & $12 \cdot 97$ & 9 & $14 \cdot 10$ & $5 \cdot 5$ \\
20 & $11 \cdot 99$ & $22 \cdot 5$ & - & - & - & - & - & - & - & - & - & - \\
25 & $11 \cdot 54$ & 11 & $13 \cdot 90$ & 4 & $11 \cdot 96$ & 13 & $14 \cdot 65$ & $6 \cdot 5$ & $12 \cdot 74$ & 9 & $12 \cdot 04$ & 18 \\
35 & - & - & $11 \cdot 99$ & 19 & - & - & $10 \cdot 59$ & 17 & $10 \cdot 74$ & 21 & - & - \\
50 & $11 \cdot 24$ & - & $11 \cdot 69$ & 13 & $11 \cdot 96$ & 14 & $10 \cdot 57$ & - & $10 \cdot 49$ & 20 & $11 \cdot 69$ & $13 \cdot 5$ \\
70 & $10 \cdot 91$ & 12 & $11 \cdot 69$ & - & $11 \cdot 94$ & 14 & $10 \cdot 39$ & - & - & - & $11 \cdot 49$ & 10 \\
90 & $*$ & $*$ & $11 \cdot 61 \dagger 10 \dagger$ & - & - & - & - & $10 \cdot 49$ & $16 \cdot 5$ & $*$ & $*$ \\
100 & $*$ & $*$ & $*$ & $*$ & $11 \cdot 89$ & - & $10 \cdot 39$ & $16 \cdot 5$ & $*$ & $*$ & $*$ & $*$
\end{tabular}

$\dagger$ Observations $5 \mathrm{~m}$. higher up than depth indicated.

\section{TABLE IX.}

Phosphate as $\mathrm{P}_{2} \mathrm{O}_{5}$ in mg. per $\mathrm{m}^{3}$ on cruise of Nov. 12th-13th, 1924 . Temperatures are also shown. Analysed Nov. 14th-18th.

\begin{tabular}{|c|c|c|c|c|c|c|c|c|c|}
\hline \multirow[b]{2}{*}{ Depth } & \multicolumn{2}{|c|}{ E1 } & \multicolumn{2}{|l|}{$\mathrm{E} 2$} & \multicolumn{2}{|l|}{ E3 } & \multicolumn{2}{|l|}{$\mathrm{Nl}$} & \\
\hline & $t^{\circ}$ & $\mathrm{P}_{2} \mathrm{O}_{5}$ & $t^{\circ}$ & $\mathrm{P}_{2} \mathrm{O}_{5}$ & $t^{\circ} \quad P$ & ${ }_{2} \mathrm{O}_{5}$ & $t^{\circ}$ & $\mathrm{P}_{2} \mathrm{O}_{5}$ & \\
\hline 0 & $12 \cdot 5$ & 14 & $12 \cdot 5$ & 6 & $13 \cdot 0$ & 12 & $12 \cdot 0$ & 19 & \\
\hline 5 & $\cdot 81$ & 20 & - & - & $13 \cdot 25 \quad 2$ & $22 \cdot 5 \quad 1$ & $12 \cdot 34$ & $21 \cdot$ & \\
\hline 10 & $\cdot 80$ & - & $12 \cdot 90$ & 23 & $13 \cdot 252$ & $22 \cdot 5 \quad 1$ & $12 \cdot 33$ & - & \\
\hline 15 & .78 & - & - & - & $13 \cdot 252$ & $22 \cdot 5 \quad 1$ & $12 \cdot 32$ & 21 & \\
\hline 25 & .80 & 20 & $12 \cdot 90$ & 25 & $13 \cdot 25 \quad 2$ & $22.5 \quad 1$ & $12 \cdot 32$ & $23 \cdot$ & \\
\hline 50 & 85 & - & $12 \cdot 90$ & - & $13 \cdot 252$ & 24 & $12 \cdot 32$ & 23 . & \\
\hline 70 & $2 \cdot 85$ & 21 & - & - & - & - & - & 一 & \\
\hline 90 & $*$ & $*$ & $12 \cdot 89 \dagger$ & $25 \dagger$ & $13 \cdot 30 \quad 2$ & 25 & $12 \cdot 32$ & 32 & \\
\hline & & & 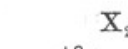 & & $\mathrm{N}$ & $N_{3}$ & & E6 & \\
\hline Dept & $t^{\circ}$ & $\mathrm{P}_{2} \mathrm{O}_{5}$ & $t^{\circ}$ & $\mathrm{P}_{2}$ & $t^{\circ}$ & $\mathrm{P}_{2} \mathrm{O}_{5}$ & & 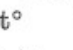 & 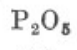 \\
\hline 0 & $12 \cdot 4$ & $24 \cdot 5$ & $12 \cdot 2$ & 10 & $12 \cdot 0$ & $28 \cdot 5$ & 11 & $1 \cdot 7$ & 12 \\
\hline 5 & - & - & - & - & - & - & & - & \\
\hline 10 & - & - & - & - & $12 \cdot 15$ & 28 & & $2 \cdot 00$ & 20 \\
\hline 15 & - & - & - & - & 一 & - & & - & - \\
\hline 25 & $2 \cdot 50$ & 19 & - & - & $12 \cdot 10$ & 28 & & $2 \cdot 00$ & \\
\hline 50 & $12 \cdot 52$ & 19 & $12 \cdot 38$ & 23 & $12 \cdot 10$ & 29 & & $2 \cdot 00$ & \\
\hline 70 & $*$ & $*$ & $*$ & $*$ & $12 \cdot 10$ & 22 & & 2.00 & \\
\hline
\end{tabular}

E7 is the International Station near the Wolf Light. X1 is half a mile off the Longships Light and X2 is $5 \frac{1}{2}$ miles off it on course to N3.

Intermediate surface values are as follows for temperature and phosphate respectively :-E1-E2, 12.8 ${ }^{\circ}, 21 \mathrm{mg}$. ; E2-E3, 12.8, $6 \mathrm{mg}$. ; E3-N1, $12 \cdot 3^{\circ}, 277 \mathrm{mg}$. ; N1-E7, $12 \cdot 1^{\circ}, 20 \mathrm{mg}$.

$$
\dagger 92 \mathrm{~m} \text {. }
$$




\section{Seasonal Changes in the Phosphate Content of the Water of the North Sea.}

Table 10 records the result of the analysis of surface and bottom samples in the shallower parts of the North Sea between the limits indicated. Of necessity a period of from a fortnight to a month elapsed between the drawing of the samples and their analysis. Their individual accuracy is somewhat impaired thereby ; for this reason and to economise in space the results of the four cruises, from which a number of samples were obtained, have been shown as averages.

\section{TABLE X.}

Surface and bottom samples, North Sea, between $0^{\circ} 2^{\prime} \mathrm{W}$. and $6^{\circ} 28^{\prime} \mathrm{E}$. and $54^{\circ} 34^{\prime} \mathrm{N}$. to $57^{\circ} 51^{\prime} \mathrm{N}$. The averaged results were from samples on lines on the course indicated. The single samples were within the given area.

\section{Date.}

May 3-6, 1923

Sept. 27-29

Feb. 8, 1924

Mar. 20-22

Apl. 6

May 5

May 31

July 8

Aug. 6 . . . . 2

Aug. 28-30 . . . 10

Oct. 19 . . . . . 16

Nov. 16 . . . . . $\quad 27$

$\mathrm{P}_{2} \mathrm{O}_{5} \mathrm{mg}$.
per $\mathrm{m}^{3}$,
bottom.

18

16

21

27

17

14

41

5

10

30

16

27

\section{Depth Number of \\ samples.}

65

67

65

68

42

43

97

50

54

71

35

40
12

11

1

8

1

1

1

1

1

7

1

1

The seasonal changes are very similar to those in the English Channel, the minimum values being found in July and early August, though in 1923 September surface samples were also almost devoid of phosphate. A considerable amount of regeneration is indicated by the August, 1924, figures, but this must have been mainly near the bottom as the October analyses show.

In Table 11 the results of phosphate-depth series are recorded for the deeper portion of the North Sea towards Norway. The gradient is very pronounced, but while the March, 1924, values are regular, those for August are the reverse; the possibility of the enrichment of the deeper 
water layers by the presence of plankton slowly sinking as it decomposes must be kept in mind. The striking thing about the August results is that the deeper water has not been denuded of phosphate to anything like the same depth that the shallower water at, say, E1 has been. The epithalassa is in this region subject to less mixing with the hypothalassa than in shallower water, which is indicated by the temperature observations also. The phosphate reserve is, therefore, not available for plant growth till it is brought nearer the surface into sufficient illumination.

Further evidence on the phosphate content of the deeper water was

\section{TABLE XI.}

Phosphate in deep water off Norway, North Sea, May 6th, at $58^{\circ} 28^{\prime}$ N., $4^{\circ} 34^{\prime}$ E. ; March 22 nd at $57^{\circ} 47^{\prime}$ N., $6^{\circ} 19^{\prime}$ E. ; and Aug. 30th, $57^{\circ} 51^{\prime}$ N., $6^{\circ} 39^{\prime}$ E. respectively.

$\begin{array}{rcccc}\begin{array}{c}\text { Depth, } \\ \text { m. }\end{array} & \text { May 6th, 1923. } & \text { Mar. 22nd, 1924. } & \text { Aug. 30th, 1924. } & \\ \mathrm{P}_{2} \mathrm{O}_{5} \text { mg. per } \mathrm{m}^{3} \text {. } & \mathrm{P}_{2} \mathrm{O}_{5} \text { mg. per m }{ }^{3} \text {. } & \mathrm{P}_{2} \mathrm{O}_{5} \text { mg. per } \mathrm{m}^{3} . & \mathrm{t}^{\circ} . \\ 0 & 14 & 22 & 20 & 16 \cdot 14 \dagger \\ 20 & - & 28 & 16 & 9 \cdot 89 \\ 50 & - & 31 & 28 & 6 \cdot 26 \\ 75 & - & - & 27 & 6 \cdot 32 \\ 100 & - & 34 & 37 & 6 \cdot 12 \\ 150 & - & 37 & 39 & 5 \cdot 97 \\ 200 & - & 37 & 30 & 5 \cdot 45 \\ 250 & - & 37 \cdot 5 & 28 & 5 \cdot 38 \\ 280 & 36 & 39 & - & - \\ 300 & * & * & 42 & 5 \cdot 19 \\ 350 & * & * & 26 & 5 \cdot 10\end{array}$

$\dagger$ At $10 \mathrm{~m} . \mathrm{t}=16 \cdot 04$. The secondary maximum at $75 \mathrm{~m}$. occurs more markedly at the station west of this, at the same depth.

sought by examining samples from around the islands north of Scotland, as set forth in Table 12 (p. 716). The really deep water north of the Wyville Thomson ridge does not show any great amount of phosphate in May, presumably it had experienced vertical mixing at no very distant date. To the south of the ridge, however, an exceptionally high value was obtained in May, also an unusually low one, such as might be met with in surface water further south. More extended observations in this region are desirable. The analyses for the August samples north of the ridge are very puzzling by reason of the high results and their irregularity. The latter may be due to storage for a month before analysis; the high 
values averaging $77 \mathrm{mg}$. per $\mathrm{m}^{3}$ may have their origin in the admixture of deep water from the Atlantic, though the temperatures are too low to use this as an explanation with any confidence, for even in May the south side of the ridge was at $8 \cdot 5^{\circ}$. Similar high and irregular values were obtained at the other Scotch stations, but the results are being held over pending confirmation by other samples. The possibility of enrichment from the glass of the bottles is also being examined by storage tests. The bottles used in August were not the ordinary spring clip milk bottles of green glass, but were of a soft white glass with waxed corks.

\section{TABLE XII.}

Surface and deep-water samples around the North of Scotland, 1924. Analysed May 2nd, June 18th, and Sept. 3rd respectively.

\begin{tabular}{|c|c|c|c|c|c|c|}
\hline Date. & Lat. N. & Long. & Locality. & $\begin{array}{l}\text { Depth in } \\
\text { metres. }\end{array}$ & $\begin{array}{l}\mathrm{P}_{2} \mathrm{O}_{5} \mathrm{mg} \text {. } \\
\text { per } \mathrm{m}^{3} \text {. }\end{array}$ & $t^{\circ}$. \\
\hline $4 / 3$ & $59^{\circ} 10^{\prime}$ & $1^{\circ} 27^{\prime} W$ & W. of Orkney Is. & 0 & 25 & 一 \\
\hline & $60^{\circ} 05^{\prime}$ & $0^{\circ} 48^{\prime} \mathrm{W}$. & W. of Shetland Is. & $\begin{array}{l}104 \\
115\end{array}$ & $25 \cdot 5$ & - \\
\hline $\begin{array}{l}-4 / 0 \\
9 / 3\end{array}$ & $60^{\circ} 02^{\prime}$ & $1^{\circ} 10^{\prime} \mathrm{W}$ & $\begin{array}{l}\text { W. of Shetland Is. } \\
\text { W. of Shetland Is. }\end{array}$ & $\begin{array}{l}115 \\
123\end{array}$ & $\begin{array}{l}25 \\
24 \cdot 5\end{array}$ & - \\
\hline $21 / 3$ & $58^{\circ} 44^{\prime}$ & $6^{\circ} 00^{\prime} \mathrm{W}$. & W. of N. of Scotland & 0 & 20 & - \\
\hline $6 / 5$ & $61^{\circ} 21^{\prime}$ & $4^{\circ} 06^{\prime} \mathrm{W}$. & East of $1000 \mathrm{~m}$. line off S. of & 120 & 21 & - \\
\hline & & 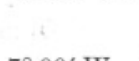 & $\begin{array}{l}\text { Faroe Is., N.E. of Wyville } \\
\text { Thomson ridge. }\end{array}$ & $\{1100$ & $\begin{array}{l}22 \\
22\end{array}$ & $\begin{array}{l}-0.56 \\
-0.94\end{array}$ \\
\hline \multirow[t]{5}{*}{$22 / 5$} & $59^{\circ} 34^{\prime}$ & $7^{\circ} 00^{\prime} \mathrm{W}$ & $\begin{array}{l}\text { On bend of } 1000 \mathrm{~m} \text {. line, } \\
\mathrm{S} \text {. of Wyville Thomson } \\
\text { ridge. }\end{array}$ & $\begin{array}{l}300 \\
800\end{array}$ & $\begin{array}{r}8 \\
79\end{array}$ & $\begin{array}{l}8 \cdot 81 \\
8 \cdot 52\end{array}$ \\
\hline & & & & 0 & 74 & $11 \cdot 08$ \\
\hline & & & & 10 & 76 & 11.02 \\
\hline & & & & 25 & 54 & $10 \cdot 48$ \\
\hline & $\cdots$ & & & $\begin{array}{l}50 \\
75\end{array}$ & $\begin{array}{l}85 \\
54\end{array}$ & $\begin{array}{l}8 \cdot 89 \\
7 \cdot 83\end{array}$ \\
\hline \multirow[t]{7}{*}{$5 / 8$} & $61^{\circ} 10^{\prime}$ & $4^{\circ} 30^{\prime} \mathrm{W}$ & E. of $1000 \mathrm{~m}$. line, S. of & 100 & 57 & $7 \cdot 80$ \\
\hline & & & Faroe Is., N.E. of Wyville & 150 & 85 & $7 \cdot 51$ \\
\hline & & & Thomson ridge. & 200 & 68 & $7 \cdot 40$ \\
\hline & & & & $\begin{array}{l}300 \\
400\end{array}$ & $\begin{array}{l}66 \\
83\end{array}$ & $\begin{array}{l}5 \cdot 12 \\
3 \cdot 86\end{array}$ \\
\hline & & & & 500 & $\begin{array}{l}85 \\
91\end{array}$ & $0 \cdot 70$ \\
\hline & & & & 600 & 94 & $0 \cdot 25$ \\
\hline & & & & 775 & 109 & -0.50 \\
\hline
\end{tabular}

\section{Phosphate Content of the Atlantic Ocean and other Waters.}

In Table 13 are recorded the results from samples from the Irish Channel, which are very similar to those in the English Channel at the same seasons, also one station 80 miles S.W. of the Fastnet Light. This had on Nov. 19th the same phosphate content as El had on Nov, 12th, but the deeper water $310 \mathrm{~m}$. gave the high value $44 \mathrm{mg}$.

An interesting series is provided by the run from England to Ceylon, shown in Table 14. Sea water sent out in the case of boxes was analysed 


\section{TABLE XIII.}

Surface and bottom samples, Irish Channel and Atlantic. Analysed May 5th, Aug. 20th, and Dec. 11th respectively.

\begin{tabular}{|c|c|c|c|c|c|}
\hline Date taken. & Lat. N. & Long. W. & $t^{\circ}$. & $\begin{array}{c}\mathrm{P}_{2} \mathrm{O}_{5} \mathrm{mg} . \\
\text { per m. }\end{array}$ & $\begin{array}{l}\text { Depth in } \\
\text { metres. }\end{array}$ \\
\hline Mar. 4th. & . $53^{\circ} 22^{\prime}$ & $5^{\circ} 30^{\prime}$ & $7 \cdot 24$ & 18,18 & 0 \\
\hline, & . & & $7 \cdot 26$ & 20,24 & 93 \\
\hline June 27th & . $49^{\circ} 20^{\prime}$ & $8^{\circ} 00^{\prime}$ & 15.24 & 3 & 0 \\
\hline , & . & , & $10 \cdot 11$ & 28 & 133 \\
\hline Nov. 19th & . $50^{\circ} 28^{\prime}$ & $10^{\circ} 49^{\prime}$ & - & 14 & 0 \\
\hline , & , & , & - & 41 & 150 \\
\hline , & . $\quad$, & , & - & 44 & 310 \\
\hline
\end{tabular}

\section{TABLE XIV.}

Surface samples (3 metres) collected between Liverpool and Colombo on Feb. 2nd to 23rd, 1924, inclusive. These are given in $\mathrm{mg}$. of $\mathrm{P}_{2} \mathrm{O}_{5}$ per cubic metre, both as analysed and corrected for change during storage by a factor $(\times 2 \cdot 3)$ obtained from the alteration in sea-water blanks sent out with the bottles. Analysed May 8th.

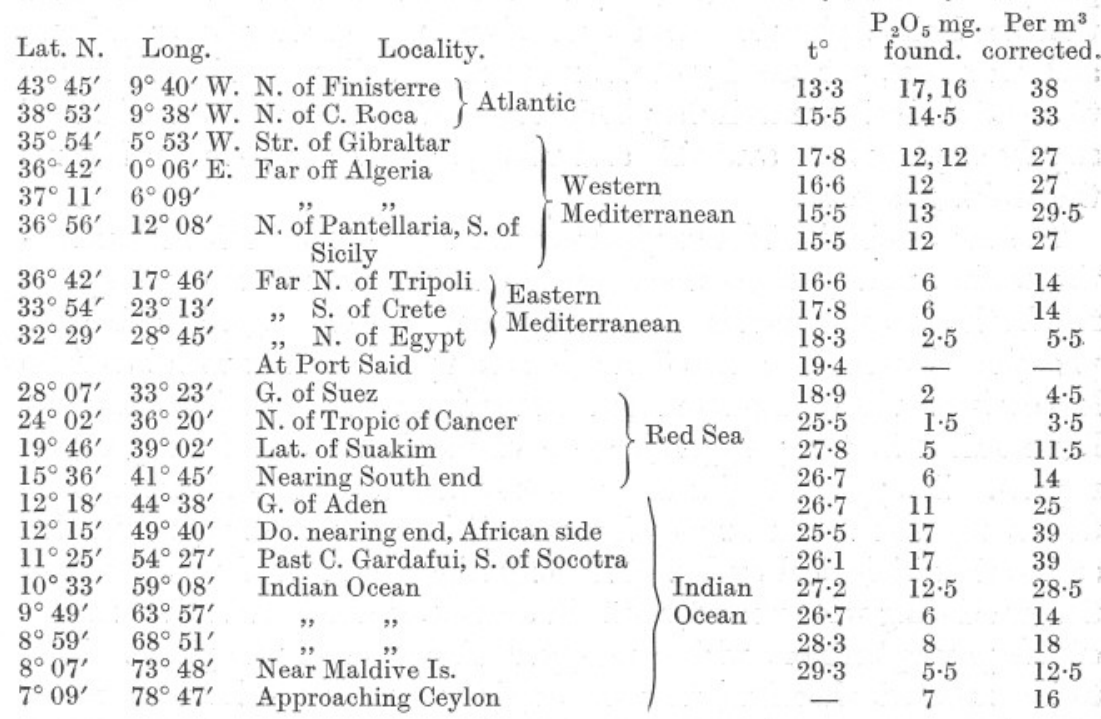

again on its return, and the very large correction thus found and applied is, it must be admitted, of doubtful validity. The results of this series are, however, of remarkable uniformity, when grouped according to locality. They bring out clearly the fact that the phosphate concentra- 
tions near the surface in the Eastern Mediterranean and the Red Sea are in February similar to summer concentrations here. Furthermore, the high values found in the Atlantic are rather similar to those recorded for the region of the Indian Ocean which bathes Gardafui; this and the lower temperatures found around the latter indicate that vertical mixing is taking place more markedly than in the open ocean further south.

A similar series was obtained from the sailing ship, St. George, between England and Panama. The first samples were taken on April 16th and the last on June 8th, 1924. The analyses were made on July 24th-25th, so the storage error must be considerable. The following values were obtained: Off Portugal and Morocco two samples, average $21 \mathrm{mg}$. per m. ${ }^{3}$; open Atlantic, sixteen samples, average $7 \mathrm{mg}$. per $\mathrm{m}^{3}$; and Caribbean Sea, seven samples, average $3 \mathrm{mg}$. per $\mathrm{m}^{3}$ These in general show that almost all the phosphate is used up in the well-illuminated southern waters, so that the conditions are similar to those for the English Channel in July.

The whole weight of evidence afforded by the phosphate determinations, recorded in this paper and in Part $I$ is in favour of the view that where illumination is adequate the phytoplankton increases till the phosphate is almost absolutely used up. From this it may be concluded that the lack of phosphate limits the abundance of the phytoplankton, and, therefore, of necessity of the zooplankton. It would be of interest to ascertain by how much the plankton would increase were an unlimited supply of phosphate available and what substance would then become the limiting factor.

The results obtained for tropical waters indicate that in them illumination is always adequate, so that at any given time the amount of phosphate free in the water as such is small. Apparently as one organism liberates phosphate by death or excretion it is used up by another with but little loss of time. The change from summer to winter conditions is accordingly less marked in the phosphate cycle of tropical than of temperature regions. It appears legitimate to conclude that in northern regions the change from summer to winter conditions is more marked in this as in other biological cycles. The long nights and the low altitude of the sun during winter must result in a great diminution in the amount of the phytoplankton, with consequent liberation of phosphate. It is to be expected, therefore, that the arctic waters should have a greater phosphate concentration during winter than those around the British Isles. Furthermore, at all times mixing of surface water with deeper water is more easily effected the nearer that water is to its temperature of maximum density, as explained in an accompanying paper by the author. With the advent of increased sunshine and long days these 
northern waters produce accordingly the abundant plankton for which they are noted.

\section{METHOD OF ANALYSIS.}

As explained in Part I the phosphate estimations were made by means of the coeruleo-molybdate colorimetric method of Denigès, using Hehner tubes for the comparison in preference to either a Duboscq or Kober colorimeter. The comparisons were made against a standard of $\mathrm{KH}_{2} \mathrm{PO}_{4}$ preserved with toluene. The working standard was equivalent to 0.50 mg. $\mathrm{P}_{2} \mathrm{O}_{5}$ per litre, and as a rule this was diluted, 10 c.c. to 100 c.c., for use. This concentration, $0.050 \mathrm{mg}$. per litre, gives a depth of clear blue which is convenient for work with natural waters. The solutions used were :-

(a) 100 c.c. of 10 per cent ammonium molybdate plus 300 c.c. of 50 per cent (by volume) sulphuric acid. Of this mixture 2 c.c. is added to 100 c.c. of the sample. The reagent should be stored in the dark to minimise the spontaneous production of a blue tint.

(b) Stannous chloride, freshly prepared from $0 \cdot 1$ grm. tin dissolved in 2 c.c. of hydrochloric acid with one drop of 3-4 per cent copper sulphate and made up to 10 c.c. It was at first usual to add five drops of this mixture, following Florentin's proportions. However, a yellow tint which developed in the sample, though not in the standard, constituted a source of trouble. It has now been found that by adding only the minimum amount of stannous chloride this trouble is obviated and the blue tint remains. Usually it suffices to add one drop to each 100 c.c. of sea water.

To convert the conventional $\mathrm{P}_{2} \mathrm{O}_{5}$ values into the more rational values for the $\mathrm{PO}_{4}$ ion the factor $1 \cdot 338$, or very approximately $\frac{4}{3}$, may be used to multiply the former.

In conclusion, the writer wishes to acknowledge his indebtedness and to express his thanks to Mr. H. W. Harvey and other members of the Laboratory staff and the crew of the Salpa for assistance in temperature observations and in the obtaining of water samples; also to Dr. Russell, Mr. J. R. Lumby, and staff of the Fisheries Laboratory, Lowestoft, for water samples; to Dr. Bowman, Mr. R. S. Clark, and staff of the Scotch Fisheries Department, Aberdeen, and to Mr. G. P. Farran, of the Irish Fisheries Department, for water samples. The author is also indebted to Mr. R. S. White and to Capt. Elliott, Mr. Davidson, Chief Engineer, and Mr. Jackson, of the City of Exeter, for the interesting samples extending to Ceylon, and to Dr. Cyril Crossiey, of the St. George, for the Panama series. 


\section{SUMMARY}

1. The seasonal changes in the sea water of the English Channel and of Plymouth Sound have now been followed for almost two years, and the second year's results closely resemble those of the first, and again confirm the earlier surface results obtained by Matthews. For 1923 the average consumption at Station E1, surface to bottom, 70 metres, was $29.6 \mathrm{mg}$. of $\mathrm{P}_{2} \mathrm{O}_{5}$ per cubic metre, leaving a balance of $7 \cdot 4 \mathrm{mg}$. out of the original $37 \mathrm{mg}$. For 1924 the corresponding figures were, used up $28.3 \mathrm{mg}$., balance $8.7 \mathrm{mg}$., winter concentration $37 \mathrm{mg}$. The minimum average value was obtained in June and July in 1924, in July only in 1923. During June, July, and August, 1924, the surface water was almost entirely denuded of phosphate, values from 1.5 to $2.5 \mathrm{mg}$. per cubic metre being obtained. These figures would be milligrams per metric ton if fresh water were being considered, as it is they are milligrams per $1027 \mathrm{~kg}$. for water of $\mathrm{S} 35.3 \%$ at $11^{\circ} \mathrm{C}$, so it may be appreciated that very little phosphate remains unutilized by the phytoplankton.

2. Owing probably to the high sunshine record for March the year 1924 was over a month ahead of 1923 in the spring as regards phosphate consumption, and, therefore, it may be presumed in the multiplication of the phytoplankton. At the same time, in the attainment of definite temperatures 1924 lagged about a month behind 1923 in spring. Since temperature has such a marked effect upon the rate of development of the plankton as a whole it appears that the zooplankton must have been retarded in 1924 as compared with 1923.

3. Samples obtained from the tropics show that even in winter phosphate may be much diminished, for the light is bright. The periodic alterations in phosphate content are, therefore, suppressed or much reduced as compared with the temperature zones. It is indicated that in arctic latitudes the sea becomes even richer in phosphate during winter than it does here, accordingly the summer development of phytoplankton is all the more abundant. 